FINANCIAL: Jurnal Akuntansi

Published by Program Studi Akuntansi STIE Sultan Agung Volume 5-Nomor 2, Desember 2019, (HIm 40-49)

ISSN-P: 2502-4574, ISSN-E: 2686-2581

Available online at: https://financial.ac.id/index.php/financial

\title{
ANALISIS DU PONT SYSTEM DALAM MENGUKUR KINERJA KEUANGAN PERUSAHAAN PADA PT FAST FOOD INDONESIA, TbK YANG TERDAFTAR DI BURSA EFEK INDONESIA
}

\author{
Yuni Rezki Hutasoit $^{1{ }^{1} *}$, Yansen Siahaan ${ }^{2)}$, Debi Eka Putri ${ }^{3)}$, Ernest Grace ${ }^{4)}$ \\ ${ }^{1,2,3,4}$ Program Studi Akuntansi, STIE Sultan Agung, Pematangsiantar, Sumatera Utara, Indonesia. \\ *E-mail: ${ }^{1}$ yunihtst26@ gmail.com, ${ }^{2}$ yansensiahaan@ \\ ${ }^{3}$ debiekaputri@stiesultanagung.ac.id, ${ }^{4}$ ernestgrace@ @stiesultanagung.ac.id
}

\begin{abstract}
Abstrak
Dalam menganalisis kinerja keuangan perusahaan dapat dilakukan dengan menggunakan metode du pont system. Du pont system merupakan bagan yang dirancang untuk menunjukkan pengembalian atas aset yang diperoleh dari perkalian marjin laba dengan total perputaran total aset. Tujuan penelitian ini adalah: Untuk mengetahui gambaran kinerja keuangan dengan menggunakan metode du pont system dan untuk mengetahui faktor-faktor yang menyebabkan penurunan kinerja keuangan dengan menggunakan analisis $d u$ pont system pada PT Fast Food Indonesia, Tbk yang Terdaftar di Bursa Efek Indonesia. Penelitian ini dilakukan dengan metode analisis deskriptif kualitatif. Objek penelitian ini adalah laporan keuangan PT Fast Food Indonesia, Tbk yang telah diaudit periode 2013 sampai 2017. Pengumpulan data dilakukan dengan metode dokumentasi. Teknik analisis yang digunakan adalah analisis deskriptif kualitatif dan analisis induktif. Hasil analisis dapat disimpulkan bahwa Net Profit Margin (NPM), Asset Turnover (ATO), Return On Asset (ROA) dan Return On Equity (ROE) mengalami penurunan sehingga kinerja keuangan perusahaan tersebut mengalami penurunan dan buruk. Equity Multiplier mengalami peningkatan. Faktor yang dominan menyebabkan penurunan kinerja perusahaan adalah beban pokok penjualan, beban penjualan dan distribusi, beban umum dan administrasi, beban operasi lainnya, meningkatnya beban pajak penghasilan, beban keuangan dan adanya pajak final atas penghasilan keuangan Hasil penelitian ini menyarankan sebaiknya perusahaan lebih memaksimalkan penggunaan aset, mengoptimalkan penjualan dan lebih meminimalkan beban beban.
\end{abstract}

Kata kunci: Analisis Du pont System, Kinerja Keuangan

\section{DU PONT ANALYSIS SYSTEM FOR MEASURING THE FINANCIAL PERFORMANCE COMPANY AT PT FAST FOOD INDONESIA Tbk REGISTERED ON THE INDONESIA STOCK EXCHANGE} Abstract

Analyzing the financial performance at the company's can be using the du pont system method. Du pont system is a chart designed to show the return on assets obtained from the multiplication of profit margins with the total turnover of total assets. The purpose of this research are: to determine the description of financial performance using the du pont system method. And To determine the factors that cause a decrease in financial performance by using the du pont analysis system at PT Fast Food Indonesia, Tbk, listed on the Indonesia Stock Exchange. This research was conducted using descriptive analysis method. The object of this research is the report PT Fast Food Indonesia, Tbk audited period of 2013 to 2017. Data collecion was out by documentation method. The analysis technique used is descriptive analysis and inductive analysis. This result of this research be concluded as Net Profit Margin (NPM), Asset Turnover (ATO), Return On Asset (ROA) and Return On Equity (ROE) has decrease so that the financial performance of the company has decreased. Equity Multiplier has increased. The dominant factors causing a decline in company performance were cost of goods sold, sales and distribution expenses, general and administrative expenses, other operating expenses, increased income tax expense, financial expenses and the existence of final tax on financial income. The result of the analysis suggest to maximize use of the assets, optimize sales and minimize the burden on the company.

Keywords: Analysis of Du Pont System, Financial Performance

Article History: Received: 14 Okt 2019 Revised: 19 Okt 2019 Accepted: 23 Nop 2019 


\section{PENDAHULUAN}

Pada era industri generasi keempat, kinerja dan passion perusahaan adalah hal yang menjadi kunci keberhasilan meraih prestasi perusahaan dengan baik. Kinerja keuangan adalah pencapaian prestasi perusahaan pada suatu periode yang menggambarkan kondisi keuangan perusahaan.

Untuk menganalisis kinerja keuangan perusahaan dapat dilakukan dengan menggunakan metode $d u$ pont system. Du pont system merupakan bagan yang dirancang untuk menunjukkan pengembalian atas aset yang diperoleh dari perkalian marjin laba dengan total perputaran total aset. Dengan menggunakan analisis ini, dapat menggambarkan kondisi perusahaan secara keseluruhan yang mencakup tingkat efisiensi perusahaan dalam penggunaan aktivanya dan memperoleh laba bersih atas penjualan produk yang dihasilkan oleh perusahaan tersebut.

Objek penelitian ini adalah PT Fast Food Indonesia Tbk yang terdaftar di Bursa Efek Indonesia yang bergerak di bidang makanan dan restoran. Berikut disajikan data Return On Equity (ROE) pada PT Fast Food Indonesia Tbk yang terdaftar di Bursa Efek Indonesia.

\section{Tabel 1}

Gambaran Return On Equity (ROE) PT Fast

Food Indonesia, Tbk yang Terdaftar di Bursa

Efek Indonesia Tahun 2013-2017

\begin{tabular}{|c|c|}
\hline Tahun & ROE (Kali) \\
\hline 2013 & 0,14 \\
\hline 2014 & 0,13 \\
\hline 2015 & 0,09 \\
\hline 2016 & 0,14 \\
\hline 2017 & 0,13 \\
\hline
\end{tabular}

Sumber: Laporan Keuangan PT Fast Food

Indonesia, Tbk (Data Diolah), 2019

Pada Tabel 1 di atas, dapat dilihat bahwa nilai rata-rata Return On Equity
(ROE) PT Fast Food Indonesia, Tbk yang terdaftar di Bursa Efek Indonesia selama periode 2013-2017 mengalami fluktuasi dan cenderung menurun. Nilai Return On Equity (ROE) menunjukkan nilai rata-rata sebesar 0,13 kali. Hal ini disebabkan oleh nilai Net Profit Margin (NPM) dan Asset Turnover mengalami penurunan sedangkan Equity Multiplier mengalami kenaikan. Hal ini tidak sejalan dengan teori yang dikemukakan oleh Brigham dan Joel (2010:146), "rasio profitabilitas mencerminkan hasil akhir dari kebijakan keuangan dan keputusan operasional. Karena profitabilitas merupakan sekelompok rasio yang menunjukkan kombinasi dari pengaruh likuiditas, manajemen aktiva, dan utang terhadap hasil operasi".

Rumusan masalah dalam penelitian ini adalah Bagaimana gambaran kinerja keuangan dengan menggunakan metode $d u$ pont system. dan Faktor-faktor yang menyebabkan penurunan kinerja keuangan dengan menggunakan analisis $d u$ pont system pada PT Fast Food Indonesia, Tbk yang Terdaftar di Bursa Efek Indonesia. Sedangkan tujuan dalam penelitian ini adalah untuk mengetahui Bagaimana gambaran kinerja keuangan dengan menggunakan metode $d u$ pont system. dan Faktor-faktor yang menyebabkan penurunan kinerja keuangan dengan menggunakan analisis $d u$ pont system pada PT Fast Food Indonesia, Tbk yang Terdaftar di Bursa Efek Indonesia.

\section{LANDASAN TEORI}

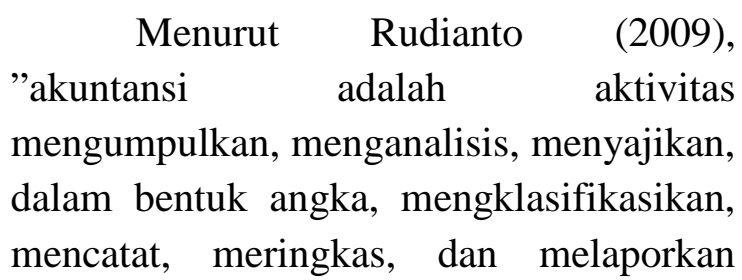


aktivitas atau transaksi perusahaan dalam bentuk informasi keuangan”. Menurut Sari dalam penelitiannya (2017), "analisis laporan keuangan adalah suatu proses penguraian data (informasi) yang terdapat dalam laporan keuangan menjadi komponen-komponen tersendiri, menelaah setiap komponen, dan mempelajari hubungan antar komponen tersebut dengan menggunakan teknik analisis tertentu agar memperoleh pemahaman yang tepat dan gambaran yang komprehensif tentang informasi tersebut".

Menurut Mulyadi dalam Irmaningsih (2017), "kinerja keuangan perusahaan adalah penentuan secara periodik efektivitas operasional suatu organisasi, bagian organisasi, dan karyawan.' Menurut J. Ferd Weston dan Fligene F. Brigham dalam Irmaningsih (2017), "du pont analysis adalah analisa yang mencakup seluruh rasio aktivitas dan margin keuntungan atas penjualan untuk menunjukkan bagaimana rasio ini mempengaruhi profitabilitas".

Menurut Syahyunan (2015), rasiorasio yang digunakan dalam du pont system adalah sebagai berikut:

1. Asset Turnover, menunjukkan kemampuan perusahaan dalam mengelola seluruh aset/investasi untuk menghasilkan penjualan.

2. Net Profit Margin (Return On Sales), menunjukkan berapa besar keuntungan bersih yang diperoleh perusahaan.

3. Return On Investment (Return On Asset), mengukur tingkat pengembalian dari bisnis atas aset yang dimiliki perusahaan.

4. Asset Leverage, sering juga disebut dengan pengganda ekuitas (equity multiplier) menggambarkan seberapa besar ekuitas atau modal jika dibandingkan dengan total aset perusahaan atau seberapa besar aset dibiayai oleh hutang.

5. Return on Equity, mengukur tingkat pengembalian dari bisnis atas seluruh modal yang ada. ROE dalam du pont system dihitung dengan mengalikan ROA dengan Equity Multiplier.

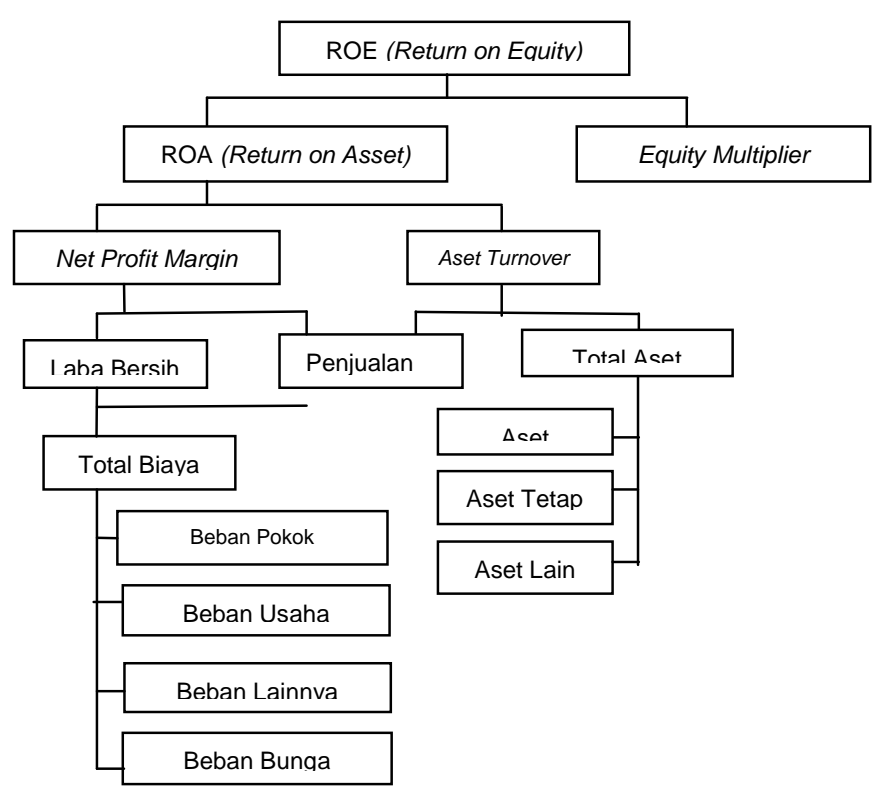

Sumber: Syahyunan (2015)

Gambar 1

Bagan Du Pont System

Hubungan Du Pont System dengan Kinerja Keuangan, adalah Menurut Brigham dan Joel (2010), "rasio profitabilitas mencerminkan hasil akhir dari kebijakan keuangan dan keputusan operasional. Karena profitabilitas merupakan sekelompok rasio yang menunjukkan kombinasi dari pengaruh likuiditas, manajemen aktiva, dan utang terhadap hasil operasi". Oleh karena itu, perlu dilakukan analisis rasio profitabilitas perusahaan untuk melihat efektivitas pengelolaan manajemen dalam bidang keuangan. Dengan meningkatnya profitabilitas suatu perusahaan, maka kinerja keuangan perusahaan tersebut dianggap telah berhasil, yang berarti 
perusahaan mampu mencapai target laba yang telah ditentukan.

\section{METODE}

Penelitian ini menggunakan data sekunder dengan meihat data laporan keuangan PT Fast Food Indonesia Tbk yang terdaftar di Bursa Efek Indonesia.yang telah diaudit periode 20132017. Desain penelitian ini adalah penelitian kepustakaan (library research). Teknik analisis data yang digunakan adalah analisis deskriptif kualitatif dan induktif.

\section{HASIL DAN PEMBAHASAN}

\section{Analisis Net Profit Margin (NPM)}

Rasio ini merupakan rasio yang digunakan untuk menunjukkan seberapa besar keuntungan bersih yang diperoleh perusahaan. Net Profit Margin (NPM) diperoleh dengan cara membagi laba bersih dengan pendapatan bersih.

Berikut data yang dimiliki PT Fast Food Indonesia, Tbk yang terdaftar di Bursa Efek Indonesia diperoleh nilai Net Profit Margin (NPM) pada tabel 2.

\section{Tabel 2}

Gambaran NPM PT Fast Food Indonesia, Tbk yang terdaftar di BEI Periode 2013-2017

\begin{tabular}{|r|c|l|c|}
\hline & Laba Bersih & \multicolumn{1}{|c|}{$\begin{array}{c}\text { Net } \\
\text { Pendapatan } \\
\text { Bersih (Rp) }\end{array}$} & $\begin{array}{c}\text { Profit } \\
\text { Margin } \\
\text { (Kali) }\end{array}$ \\
\hline 2013 & 156.290 .628 .000 & 3.960 .252 .775 .000 & 0,0395 \\
\hline 2014 & 152.046 .069 .000 & 4.208 .887 .158 .000 & 0,0361 \\
\hline 2015 & 105.023 .728 .000 & 4.475 .061 .326 .000 & 0,0235 \\
\hline 2016 & 172.605 .540 .000 & 4.883 .307 .267 .000 & 0,0353 \\
\hline 2017 & 166.998 .578 .000 & 5.302 .683 .924 .000 & 0,0315 \\
\hline \multicolumn{3}{|c|}{ Rata-Rata } & $\mathbf{0 , 0 3 3 2}$ \\
\hline \multicolumn{3}{|c|}{ Nilai Maksimum } & $\mathbf{0 , 0 3 9 5}$ \\
\hline \multicolumn{3}{|c|}{ Nilai Minimum } & $\mathbf{0 , 0 2 3 5}$ \\
\hline
\end{tabular}

Sumber: Laporan Keuangan PT Fast Food Indonesia, Tbk (Data Diolah), 2019.

Berdasarkan Tabel 2 dapat diketahui bahwa nilai minimum Net Profit Margin (NPM) pada PT Fast Food Indonesia, Tbk terdapat pada tahun 2015 sebesar 0,0235 kali. Artinya, setiap Rp. 1 Copyright (C) 2019, FINANCIAL: Jurnal Akuntansi penjualan menghasilkan keuntungan sebesar Rp. 0,0235.

Hal ini disebabkan oleh meningkatnya beban pokok penjualan, beban penjualan dan distribusi, beban umum dan administrasi, beban operasi lainnya, beban pajak penghasilan, beban keuangan dan adanya pajak final atas penghasilan keuangan.

\section{Analisis Asset Turnover (ATO)}

Asset Turnover (ATO) menunjukkan kemampuan perusahaan dalam mengelola seluruh aset untuk menghasilkan pendapatan. Asset Turnover (ATO) diperoleh dengan cara membagi pendapatan bersih dengan total aset. Berikut disajikan data Asset Turnover (ATO) pada PT Fast Food Indonesia, Tbk yang terdaftar di Bursa Efek Indonesia periode 2013-2017.

Tabel 3

Gambaran Asset Turnover (ATO) pada PT Fast Food Indonesia, Tbk yang terdaftar di Bursa Efek Indonesia periode 2013-2017

\begin{tabular}{|r|c|c|c|}
\hline Tahun & Pendapatan (Rp) & Total Aset (Rp) & $\begin{array}{c}\text { ATO } \\
\text { (Kali) }\end{array}$ \\
\hline 2013 & 3.960 .252 .775 .000 & 2.028 .124 .663 .000 & 1,9527 \\
\hline 2014 & 4.208 .887 .158 .000 & 2.162 .633 .810 .000 & 1,9462 \\
\hline 2015 & 4.475 .061 .326 .000 & 2.310 .536 .370 .000 & 1,9368 \\
\hline 2016 & 4.883 .307 .267 .000 & 2.577 .819 .573 .000 & 1,8944 \\
\hline 2017 & 5.302 .683 .924 .000 & 2.749 .422 .391 .000 & 1,9287 \\
\hline \multicolumn{3}{|c|}{ Rata-Rata } & $\mathbf{1 , 9 3 1 7}$ \\
\hline \multicolumn{3}{|c|}{ Nilai Maksimum } & $\mathbf{1 , 9 5 2 7}$ \\
\hline \multicolumn{3}{|c|}{ Nilai Minimum } \\
\hline
\end{tabular}

Sumber: Laporan Keuangan PT Fast Food Indonesia, Tbk (Data Diolah), 2019.

Berdasarkan analisis Tabel 3 dapat dilihat bahwa Asset Turnover (ATO) pada PT Fast Food Indonesia, Tbk dari tahun 2013-2017 mengalami fluktuasi dan cenderung menurun. Hal ini disebabkan oleh penurunan persediaan, dan adanya aset pajak tangguhan. 
Untuk nilai rata-rata Asset Turnover (ATO) pada PT Fast Food Indonesia, Tbk sebesar 1,9317 kali. Artinya, setiap Rp. 1 perputaran total aset menghasilkan penjualan sebesar 1,9317 kali. Nilai Asset Turnover (ATO) yang berada di atas rata-rata adalah tahun 2013, 2014, dan 2015 dengan masing-masing nilai sebesar 1,9527 kali, 1,9462 kali dan 1,9368 kali. Sedangkan, nilai Asset Turnover (ATO) yang berada di bawah rata-rata adalah tahun 2016 dan 2017 dengan masing-masing nilai sebesar 1,8944 kali dan 1,9287 kali.

\section{Analisis Return On Asset (ROA)}

Return On Asset (ROA) menunjukkan tingkat pengembalian dari bisnis atas aset yang dimiliki perusahaan. Return On Asset (ROA) dapat diperoleh dari hasil pembagian antara laba bersih dengan total aset. Berikut disajikan data Return On Asset (ROA) pada PT Fast Food Indonesia, Tbk yang terdaftar di BEI periode 2013-2017 pada Tabel 4.

Tabel 4

Gambaran Return On Asset (ROA) pada PT Fast Food Indonesia, Tbk yang

terdaftar di BEI periode 2013-2017

\begin{tabular}{|c|c|c|c|}
\hline $\begin{array}{c}\text { Tahu } \\
\text { n }\end{array}$ & $\begin{array}{c}\text { Laba Bersih } \\
(\text { Rp) }\end{array}$ & \multicolumn{1}{|c|}{ Total Aset (Rp) } & $\begin{array}{c}\text { ROA } \\
(\text { Kali) }\end{array}$ \\
\hline 2013 & 156.290 .628 .000 & 2.028 .124 .663 .000 & 0,0771 \\
\hline 2014 & 152.046 .069 .000 & 2.162 .633 .810 .000 & 0,0703 \\
\hline 2015 & 105.023 .728 .000 & 2.310 .536 .370 .000 & 0,0455 \\
\hline 2016 & 172.605 .540 .000 & 2.577 .819 .573 .000 & 0,0670 \\
\hline 2017 & 166.998 .578 .000 & 2.749 .422 .391 .000 & 0,0607 \\
\hline \multicolumn{3}{|c|}{ Rata-Rata } & $\mathbf{0 , 0 6 4 1}$ \\
\hline \multicolumn{3}{|c|}{ Nilai Maksimum } & $\mathbf{0 , 0 7 7 1}$ \\
\hline Nilai Minimum & $\mathbf{0 , 0 4 5 5}$ \\
\hline Sumber: & Laporan Keuangan PT Fast Food \\
\hline \multicolumn{3}{|c|}{ Indonesia, Tbk (Data Diolah), 2019. }
\end{tabular}

Berdasarkan Tabel 4 dapat dilihat bahwa Return On Asset (ROA) pada PT Fast Food Indonesia, Tbk dari tahun 20132017 mengalami fluktuasi dan cenderung menurun. Hal ini disebabkan oleh penurunan laba bersih yang tidak diseimbangi dengan total aset.

Untuk nilai rata-rata Return On Asset (ROA) pada PT Fast Food Indonesia, Tbk sebesar 0,0641 kali. Artinya setiap Rp. 1 total aset menghasilkan laba sebesar Rp. 0,0641. Nilai Return On Asset (ROA) yang berada di atas rata-rata adalah tahun 2013, 2014 dan 2016 dengan masing-masing nilai sebesar 0,0771 kali, 0,0703 dan 0,0670 kali. Sedangkan, nilai Return On Asset (ROA) yang berada di bawah ratarata adalah tahun 2015 dan 2017 dengan masing-masing nilai sebesar 0,0455 kali dan 0,0607 kali.

\section{Analisis Equity Multiplier}

Equity multiplier menggambarkan seberapa besar ekuitas atau modal jika dibandingkan dengan total aset perusahaan atau seberapa besar aset dibiayai oleh modal sendiri. Equity multiplier diperoleh dari hasil pembagian antara total aset dengan total ekuitas. Berikut disajikan data equity multiplier pada PT Fast Food Indonesia, Tbk yang terdaftar di Bursa Efek Indonesia periode 2013-2017 Tabel 5.

\section{Tabel 5}

Gambaran Equity Multiplier pada PT Fast Food Indonesia, Tbk yang terdaftar di BEI periode 2013-2017

\begin{tabular}{|r|c|c|c|}
\hline Tahun & Total Aset (Rp) & Total Ekuitas (Rp) & $\begin{array}{c}\text { Equity } \\
\text { Multiplier } \\
\text { (Kali) }\end{array}$ \\
\hline 2013 & 2.028 .124 .663 .000 & 1.100 .971 .775 .000 & 1,8421 \\
\hline 2014 & 2.162 .633 .810 .000 & 1.193 .163 .687 .000 & 1,8125 \\
\hline 2015 & 2.310 .536 .370 .000 & 1.114 .917 .330 .000 & 2,0724 \\
\hline 2016 & 2.577 .819 .573 .000 & 1.223 .210 .987 .000 & 2,1074 \\
\hline 2017 & 2.749 .422 .391 .000 & 1.293 .570 .812 .000 & 2,1255 \\
\hline \multicolumn{3}{|c|}{ Rata-Rata } & $\mathbf{1 , 9 9 2 0}$ \\
\hline \multicolumn{3}{|c|}{ Nilai Maksimum } & $\mathbf{2 , 1 2 5 5}$ \\
\hline \multicolumn{3}{|c|}{ Nilai Minimum } & $\mathbf{1 , 8 1 2 5}$ \\
\hline
\end{tabular}

Sumber: Laporan Keuangan PT Fast Food Indonesia, Tbk (Data Diolah), 2019.

Berdasarkan Tabel 5 dapat dilihat bahwa Equity Multiplier pada PT Fast Food Indonesia, Tbk dari tahun 2013-2017 mengalami fluktuasi dan cenderung 
meningkat. Hal ini disebabkan oleh meningkatnya saldo laba yang telah ditentukan penggunaannya untuk cadangan umum, meningkatnya saldo laba yang belum ditentukan penggunaannya, dan adanya aset pajak tangguhan.

Untuk hasil rata-rata Equity Multiplier mengalami fluktuasi dan cenderung meningkat sebesar 1,9920 kali. Artinya setiap Rp. 1 aset perusahaan dibiayai oleh ekuitas sebesar Rp. 1,9920. Nilai Equity Multiplier yang berada di atas rata-rata adalah tahun 2015, 2016 dan 2017 dengan masing-masing nilai sebesar 2,0724 kali, 2,1074 kali dan 2,1255 kali. Sedangkan, nilai Equity Multiplier yang berada di bawah rata-rata adalah tahun 2013 dan 2014 dengan masing-masing nilai sebesar 1,8421 kali dan 1,8125 kali.

\section{Return On Equity (ROE)}

Return On Equity (ROE) mengukur tingkat pengembalian dari bisnis atas seluruh modal yang ada. ROE dalam $D u$ Pont System dihitung dengan mengalikan ROA dengan Equity Multiplier. Berikut disajikan data Return On Equity (ROE) pada PT Fast Food Indonesia, Tbk yang terdaftar di Bursa Efek Indonesia periode 2013-2017 pada Tabel 6.

\section{Tabel 6}

Gambaran Return On Equity (ROE) pada PT Fast Food Indonesia, Tbk yang terdaftar di Bursa Efek Indonesia periode 2013-2017

\begin{tabular}{|c|c|c|c|}
\hline Tahun & $\begin{array}{c}\text { ROA } \\
\text { (Kali) }\end{array}$ & $\begin{array}{c}\text { Equity } \\
\text { Multiplier } \\
\text { (Kali) }\end{array}$ & $\begin{array}{c}\text { ROE } \\
\text { (Kali) }\end{array}$ \\
\hline 2013 & 0,0771 & 1,8421 & 0,1420 \\
\hline 2014 & 0,0703 & 1,8125 & 0,1274 \\
\hline 2015 & 0,0455 & 2,0724 & 0,0942 \\
\hline 2016 & 0,0670 & 2,1074 & 0,1411 \\
\hline 2017 & 0,0607 & 2,1255 & 0,1291 \\
\hline
\end{tabular}

\begin{tabular}{|c|c|}
\hline Rata-Rata & $\mathbf{0 , 1 2 6 8}$ \\
\hline Nilai Maksimum & $\mathbf{0 , 1 4 2 0}$ \\
\hline Nilai Minimum & $\mathbf{0 , 0 9 4 2}$ \\
\hline
\end{tabular}

Sumber: Laporan Keuangan PT Fast Food Indonesia, Tbk (Data Diolah), 2019.

Berdasarkan Tabel 6 dapat dilihat bahwa Return On Equity (ROE) pada PT Fast Food Indonesia, Tbk dari tahun 20132017 mengalami fluktuasi dan cenderung menurun. Hal ini disebabkan oleh meningkatnya beban penjualan dan distribusi, beban umum dan administrasi dan adanya pajak final atas penghasilan keuangan.

Untuk hasil rata-rata Return On Equity (ROE) mengalami fluktuasi dan cenderung menurun sebesar 0,1268 kali. Artinya setiap Rp. 1 total ekuitas mampu menghasilkan keuntungan sebesar Rp. 0,1268. Nilai Return On Equity (ROE) yang berada diatas rata-rata adalah tahun 2013, 2014, 2016 dan 2017 dengan masing-masing nilai sebesar 0,1420 kali, 0,1274 kali, 0,1411 dan 0,1291 kali. Sedangkan, nilai Return On Equity (ROE) yang berada dibawah rata-rata adalah tahun 2015 dengan nilai sebesar 0,0942 kali.

\section{Evaluasi}

Evaluasi Kinerja Keuangan PT Fast Food Indonesia, Tbk dengan Metode Du Pont System

\section{Evaluasi Net Profit Margin (NPM)}

Dari hasil analisis Net Profit Margin (NPM) PT Fast Food Indonesia, Tbk yang terdaftar di Bursa Efek Indonesia perusahaan mengalami fluktuasi dan cenderung menurun. Hal ini disebabkan oleh meningkatnya beban pokok penjualan, beban penjualan dan distribusi, beban umum dan administrasi, beban operasi lainnya, meningkatnya beban pajak 
penghasilan, beban keuangan dan adanya pajak final atas penghasilan keuangan. Sebaiknya, perusahaan lebih meminimalkan beban-beban seperti beban penjualan dan distribusi, beban umum dan administrasi, beban operasi lainnya, beban keuangan agar perusahaan mampu meningkatkan penjualan untuk memperoleh profit atau laba.

\section{Evaluasi Asset Turnover (ATO)}

Dari hasil analisis Asset Turnover (ATO) PT Fast Food Indonesia, Tbk yang Terdaftar di Bursa Efek Indonesia perusahaan mengalami fluktuasi dan cenderung menurun. Hal ini disebabkan oleh penurunan persediaan dan adanya aset pajak tangguhan. Sebaiknya, perusahaan mampu mengoptimalkan aset agar mampu menghasilkan penjualan yang lebih baik untuk memperoleh profit atau laba.

\section{Evaluasi Return On Asset (ROA)}

Dari hasil analisis Return On Asset (ROA) PT Fast Food Indonesia, Tbk yang Terdaftar di Bursa Efek Indonesia perusahaan mengalami fluktuasi dan cenderung menurun. Hal ini disebabkan oleh adanya pajak final atas penghasilan keuangan serta peningkatan beban penjualan dan distribusi. Sebaiknya, perusahaan mampu meningkatkan laba dengan meminimalkan beban-beban dan meningkatkan efektivitas penggunaan aset.

\section{Evaluasi Equity Multiplier}

Dari hasil analisis Equity Multiplier PT Fast Food Indonesia, Tbk yang terdaftar di Bursa Efek Indonesia perusahaan mengalami fluktuasi dan cenderung meningkat. Hal ini disebabkan oleh meningkatnya saldo laba yang telah ditentukan penggunaannya untuk cadangan umum, meningkatnya saldo laba yang belum ditentukan penggunaannya, dan adanya aset pajak tangguhan. Sebaiknya, perusahaan lebih banyak menghasilkan arus kas untuk mempertahankan kondisi operasi yang optimal.

\section{Evaluasi Return On Equity (ROE)}

Dari hasil analisis Return On Equity (ROE) PT Fast Food Indonesia, Tbk yang terdaftar di Bursa Efek Indonesia perusahaan mengalami fluktuasi dan cenderung menurun. Hal ini disebabkan oleh meningkatnya beban pokok penjualan, beban penjualan dan distribusi, beban umum dan administrasi, beban operasi lainnya, beban pajak penghasilan, beban keuangan dan adanya pajak final atas penghasilan keuangan.

Hal ini berarti kemampuan perusahaan dalam memperoleh laba dari penjualan dan total aset menurun, serta besarnya aset yang diperoleh dari ekuitas. Sebaiknya, perusahaan lebih meningkatkan penjualan, meminimalkan beban-beban dan mengoptimalkan aset agar dapat menghasilkan laba bagi perusahaan.

\section{Evaluasi Kinerja Keuangan}

Dari hasil analisis kinerja keuangan dengan menggunakan rasio Net Profit Margin (NPM), Asset Turnover (ATO), Return On Asset (ROA), Equity Multiplier dan Return On Equity (ROE) PT Fast Food Indonesia, Tbk yang terdaftar di Bursa Efek Indonesia perusahaan mengalami fluktuasi dan cenderung menurun. Hal ini disebabkan oleh meningkatnya beban pokok penjualan, beban penjualan dan distribusi, beban umum dan administrasi, beban operasi lainnya, beban pajak penghasilan, beban keuangan dan adanya pajak final atas penghasilan keuangan.

Sebaiknya, perusahaan mampu mengoptimalkan pendapatan dan mengoptimalkan aset agar mampu menghasilkan laba dan lebih 
meminimalkan beban-beban yang dapat merugikan perusahaan.

\section{KESIMPULAN DAN SARAN \\ Kesimpulan}

Berdasarkan analisis dari penelitian yang penulis lakukan, serta mengolah datadata yang diperoleh dari hasil penelitian, maka terdapat beberapa hal yang dapat disimpulkan:

Kinerja keuangan PT Fast Food Indonesia, Tbk yang diukur dengan metode $d u$ pont system menghasilkan nilai Net Profit Margin (NPM), nilai Asset Turnover (ATO), Return On Asset (ROA) dan Return On Equity (ROE) yang berfluktuasi dan cenderung menurun sedangkan nilai Equity Multiplier yang berfluktuasi dan cenderung meningkat. Hal ini disebabkan oleh meningkatnya beban pokok penjualan, beban penjualan dan distribusi, beban umum dan administrasi, beban operasi lainnya, meningkatnya beban pajak penghasilan, beban keuangan dan adanya pajak final atas penghasilan keuangan. Faktor-faktor yang menyebabkan kinerja keuangan PT Fast Food Indonesia. Tbk yang terdaftar di Bursa Efek Indonesia tahun 2013-2017 mengalami penurunan yaitu meningkatnya beban pokok penjualan, beban penjualan dan distribusi, beban umum dan administrasi, beban operasi lainnya, beban pajak penghasilan, beban keuangan dan adanya pajak final atas penghasilan keuangan.

\section{Saran}

Berdasarkan hasil analisis dan kesimpulan di atas, maka penulis dapat memberikan saran sebagai berikut:

Untuk meningkatkan nilai Net Profit Margin (NPM) sebaiknya, perusahaan

Copyright (C) 2019, FINANCIAL: Jurnal Akuntansi lebih meminimalkan beban-beban seperti beban penjualan dan distribusi, beban umum dan administrasi, beban operasi lainnya, beban keuangan pada tingkat yang seefisien mungkin agar perusahaan mampu meningkatkan penjualan untuk memperoleh profit atau laba.

Untuk meningkatkan nilai Total
Asset Turnover (TATO) sebaiknya, perusahaan mampu mengoptimalkan penggunaan aset agar mampu menghasilkan penjualan yang lebih baik untuk memperoleh profit atau laba.

Untuk meningkatkan nilai Equity Multiplier sebaiknya, perusahaan lebih banyak menghasilkan arus kas untuk mempertahankan kondisi operasi yang optimal.

Untuk meningkatkan nilai Return On Asset (ROA) dan Return On Equity (ROE) sebaiknya, perusahaan mampu meningkatkan laba dengan meminimalkan beban-beban, meningkatkan penjualan serta meningkatkan efisiensi dan efektivitas penggunaan aset.

\section{DAFTAR PUSTAKA}

Ankarath, dkk. 2012. Memahami IFRS, Standard Pelaporan Keuangan Internasional. Jakarta: Indeks.

Brigham, Eugene F., dan Joel F. Houston. 2010. Dasar-Dasar Manajemen Keuangan. Edisi 11. Jakarta: Salemba Empat.

Bursa Efek Indonesia. 2019. http//www.idx.co.id. Tahun akses 2019.

Doorasamy, Mishelle. 2016. Using Du

Pont System Analysis to Asses The Financial Performance of The Top 3 JSE Listed Companies In The Food Industry. International Joernal. University of KwaZulu-Natal Westville, Durban. Journal Internasional. Volume 13, Issue 2. https://businessperspectives.org/741 
1/imfi_en_2016_02_Doorasamy.pdf. Februari 2019.

Hery, 2015. Analisis Laporan Keuangan.

Yogyakarta: Center for Academic Publishing Service.

Hery, 2017. Teori Akuntansi. Jakarta: Grasindo.

Ikhsan, Arfan, dkk. 2018. Analisa Laporan Keuangan. Medan: Madenatera.

Irmaningsih, Dede. 2017. Analisis Penerapan Du Pont System untuk Mengukur Kinerja Keuangan Perusahaan (Studi Pada Sektor Perusahaan Makanan dan Minuman Yang Terdaftar Di Bursa Efek Indonesia Periode Tahun 2012-2015). Bandar Lampung: Universitas Lampung. Skripsi.

Maith, Hendry Andres. 2013. Analisis Laporan Keuangan Dalam Mengukur Kinerja Keuangan pada PT. Hanjaya Mandala Sampoerna, Tbk. Jurnal EMBA, Vol. 1 No. 3 September 2013, Hal 619-628, ISSN 2303-1174. Universitas Sam Ratulangi Manado. https://analisis-laporan-keuangandalam-mengukur-kinerja-keuanganpada-pt-hanjaya-mandal.pdf.

Februari 2019.

Martani, Dwi, dkk. 2012. Akuntansi Keuangan Menengah Berbasis PSAK. Jakarta: Salemba Empat.

Munawir, S. 2004. Analisa Laporan Keuangan. Edisi 4. Yogyakarta: Liberty.

........., 2010. Analisa Laporan Keuangan. Yogyakarta: Liberty.

PT Fast Food Indonesia, Tbk. htpp://www.kfcku.com. Tahun akses 2019

Rahayu, Ayu Novitri. 2017. Analisis Profitabilitas Dengan Menggunakan Pendekatan Du Pont System Pada Perusahaan Sektor Property dan Real Estate Yang Terdaftar Di Jakarta Islamic
Index. Palembang: Universitas Islam Negeri Raden Fatah Palembang. Skripsi.

Rudianto. 2009. Pengantar Akuntansi. Jakarta: Erlangga.

........, 2013. Akuntansi Manajemen. Jakarta: Erlangga.

Sari, Yensi Purnama, 2017. Analisis Kinerja Keuangan Dengan Menggunakan Metode $\mathrm{Du}$ Pont System Pada Bank Umum Syari'ah Di Indonesia. Palembang: Universitas Islam Negeri Raden Fatah Palembang. Tugas Akhir.

Soemarso, S. R. 2004. Akuntansi Suatu Pengantar. Edisi V. Cetakan Kedua. Jakarta: Salemba Empat.

Sulistiyo dan Diah. 2017. Analisis System Du Pont Sebagai Salah Satu Alat Ukur Untuk Menilai Kinerja Keuangan Perusahaan (Studi Pada Perusahaan Property Real Estate Yang Terdaftar di BEI Tahun 2010-2014). Jurnal Akuntansi, FEB, UNIPMA, Vol. 1 No. 1, Oktober 2017. Universitas PGRI Madiun. Htpps://www.researchgate.net/public ation.pdf. Februari 2019.

Syahyunan. 2015. Manajemen Keuangan. Medan: USU Press.

\section{PROFIL SINGKAT}

Yuni Rezki Hutasoit, Lahir di Pematangsiantar tanggal 26 Juni 1997, Pendidikan terakhir Sarjana Akuntansi dari STIE Sultan Agung Tahun 2019 dan saat ini bekerja sebagai Karyawan di FIF Group Cabang Pematangsiantar.

Yansen Siahaan, lahir di Pematangsiantar pada tanggal 15 Nopember tahun 1955. Menyelesaikan pendidikan Doktor pada Program Studi Ilmu Akuntansi di Universitas Sumatera Utara pada tahun 2018. Saat ini beliau menjabat sebagai Ketua Program Studi Sarjana Akuntansi di STIE Sultan Agung. 
FINANCIAL: Jurnal Akuntansi, Volume 5 Nomor 2, Desember 2019

Debi Eka Putri, Lahir di Pematangsiantar tanggal 03 Agustus 1993, Pendidikan terakhir Pascasarjana Program Studi Manajemen dari Universitas Muhammadiyah Sumatera Utara (UMSU) Tahun 2017 dan sekarang bekerja sebagai Dosen Tetap bidang Manajemen di STIE Sultan Agung.
Ernest Grace, Lahir di Pematangsiantar tanggal 01 April 1987. Pendidikan terakhir Pascasarjana Program Studi Manajemen dari Universitas HKBP Nommensen Medan Tahun 2013 dan sekarang bekerja sebagai Dosen Tetap bidang Akuntansi di STIE Sultan Agung. 